\title{
Comparison of "Course Study and Learning Strategies" Used by 9th and 12th Grade Students in Anatolian and Science High Schools
}

\author{
Mahmut Oğuz Kutlu ${ }^{1}$ \\ ${ }^{1}$ Department of Education Sciences, Çukurova University, Adana, Turkey \\ Correspondence: Mahmut Oğuz Kutlu, Department of Education Sciences, Çukurova University, Adana, Turkey. \\ E-mail: okutlu@cu.edu.tr
}

Received: October 22, 2020 Accepted: November 20, 2020 Online Published: November 25, 2020

doi:10.5539/jel.v9n6p155 URL: https://doi.org/10.5539/jel.v9n6p155

\begin{abstract}
The main aim of this study is to comparatively examine the "Studying and Learning Strategies" used by the students of Science and Anatolian High Schools, which are the general secondary instruction level in the Turkish Educational System, at Adana province example in Turkey. The study is a descriptive study, a relational survey model. The population of the study is 9th and 12th grade students who are studying in Anatolian and Science High Schools in the city center of Adana. This study group of this research is consisted of 393 students in 9th and 12th grades who were studying at Adana Science High School and Seyhan İMKB Anatolian High School in the spring term of the 2019-2020 academic year. As a data collection tool, the "Study and Learning Strategies Scale for High School Students" developed by Kutlu, Yapıcı and Korkmaz (2015), consisting of 46 items and five sub-dimensions, was used. As a result of the study, when the "Study and Learning Strategies" of the students are examined according to school types; It has been determined that there is a significant difference in the sub-dimensions of "Repetition" and "Enjoying Learning". It has been observed that there is a significant difference between male and female students in "Repetition" and "Self-Confidence" sub-dimensions according to the gender of the students. There is no significant difference between the levels of 9th and 12th grade students studying at Science and Anatolian High Schools according to their grade levels.
\end{abstract}

Keywords: study skills, learning strategies, anatolian high schools, science high schools

\section{Introduction}

Today, where learner-centered approaches are adopted, the importance of how students will learn, what they should do for better recall, how they can increase their motivation, how they can bring their stress to the appropriate level and how they can manage their own learning, etc. are accepted by all educational scientists. Dimensions such as goal setting, planned work for time management, repetition in appropriate ways, establishing horizontal and vertical associations between the subjects studied, listening and reading skills effectively, and focusing and concentration techniques are all within the scope of study and learning skills. In other words, learning should be an active process and learning mostly occurs with the active effort of the individual. In fact, we are born with the ability to learn and we do it every day of our lives, usually without even being aware of it (Rowntree, 1998, p. 1).

According to Lefrançois (2000, p. 4) learning is generally defined as all relatively permanent changes in potential for behavior that result from experience but are not due to fatigue, maturation, drugs, injury or disease. Strictly speaking, of course, learning is not defined by actual or potential changes in behavior. Rather, learning is what happens to the organism as a result of experience. Changes in behavior are simply evidence that learning has ocurred. In other words, learning can be defined as the process of perceiving, recording, remembering and using information when necessary (Türkoğlu, Doğanay, \& Yıldırım, 1996, p. 9). But no one born knowing how to study. Studying is a rather special form of learning. It is a skill that you must develop, practice, and refine (Mundsack, Deese, \& Deese, 2003, p. 19). On the other hand, most people who advise students and who know what students' problems are believe that lack of motivation is responsible for more failures than inadequate background or lack of ability. Not being motivated is about the worst academic problem a student can face (Mundsack, Deese, \& Deese, 2003, p. 19). Indeed, learning, even studying, doesn't have to be a chore. It can be a real source of satisfaction. Even learning can be an adventure (Cottrell, 1999, p. 4). It is difficult to learn if you are stressed or bored. In other words, what we learn happily is never forgotten (O’Hara, 2005, p. 57). 
A student's job is to study. As in all other jobs, success in the learning process can only be achieved through a systematic approach, effective and efficient work. The trainings that will be given to students on how to take better notes in class, how to use time more efficiently, how to read more effectively and faster, how to remember more, how to reduce forgetting and how to prepare for exams increase the success (Luckie \& Smethurst, 1998, p. 2). Learning how to learn - applying successful techniques-is like mountain climbing with a backpack equipped with appropriate tools (Frander, 2004, p. 10). Kirby (1988) states that having knowledge of students' study skills will also help them take an active role in learning processes. Pauk (1984) emphasizes that studying skills include learning, remembering and exam studies, however, he also states that the following points should be considered while studying. Remembering information; If any learned subject cannot be remembered when necessary, it means that the learning has been insufficient. It makes it very easy to remember the information learned by repeating the lessons. Skimming: Quickly review the text; It is an approach that can be used to have a general knowledge of the subject. Scanning: This strategy can be used when looking for specific information. It is often used when searching for a word in the dictionary or when searching or examining a topic in the encyclopedia. Extensive reading: This type of reading can be preferred for long texts or for pleasure. For example, when a novel or any book is read on vacation, such reading can be done. It is sufficient to understand the text read in general instead of searching for unknown words. Therefore, the text is read fluently. Intensive reading: While short texts are read in depth, this kind of reading approach can be preferred when details are needed. Reading textbooks and taking notes: Students learn most of the information in school from textbooks or while lectures are being taught, and they note what they have learned. Using resources: Students should be aware that they have many resource books that can help them achieve success in school. Finding the main idea: Students should know how to find the main idea in reading paragraphs and texts. For this, they need to learn and use reading strategies.

According to Gralett (1981), who drew attention to the individual dimension of the learning process, the student should be given responsibility in the learning process. Students should learn how to get effective and sufficient information from their books and from the relevant parts of the textbooks (from the section at the end of the textbooks, from the dictionary or index, from the explanations made on the last page, the index, etc.). Therefore, students should know how to read textbooks and note-taking strategies and use these strategies. Because working hard is not enough to be successful at school. At the same time, it is necessary to work efficiently and systematically for success. In other words, how much is studied is more important than how long it is studied. Moreover, the overall motivation to work of the person who cannot achieve success in proportion to the effort he/she spends may also decrease. Many students feel hopeless when they see that their effort and time are not getting high marks. Students who cannot develop effective study skills are inadequate in motivating themselves to learn, planning and evaluating learning processes as their grade level rises, and this affects their success at school negatively (Türkoğlu, Doğanay, \& Yıldırım, 1996, p. 1). In this context, according to Luckie and Smethurst (1998, p. 1), school success is not directly related to intelligence, quickness, ambition, or any other such characteritics. Primarily, it comes from the ability and desire to manage the work and the time effectively. Especially learning how to learn-applying successful techniques-is like mountain climbing with a backpack equipped with appropriate tools (Frander, 2004, p. 10). Improving the study skills doesn't mean spending 24 hours a day, 7 days a week studying. Becoming a better student, managing the time and organizing the work, prioritizing the assignments, getting the most from a reading assignment or lecture, and quickly handling problems are all ways to improve the success in school (O’Hara, 2005, p. 1).

Small children learn extraordinary amounts without trying particularly hard-simply through being relaxed, observing, playing, role playing, trying things out, making mistakes, and being interested in what they are doing. They don't regard setbacks as failures; they don't worry about what others think; and they don't tell themselves they might not be able to learn. When a child falls over, she or he just gets up and moves again, and eventually walking becomes easy. Adults can learn in this way too-if they allow themselves (Cottrell, 1999, p. 4).

It takes two things to be successful in life: skill and will (VanderStoep \& Pintrich, 2003, p. 8). This is true not just in academic pursuits but also in athletics, music, employment, and relationships. Successful people in all walks of life are both skillful and willful. The skill is the competencies and strategies needed to do things well. The will is the desire and motivation to do things well. Motivation, which is also defined as the key to learning (Wlodkowski \& Jaynes, 1991, p. 3), is briefly the willingness to make an effort to achieve a goal and there is a strong link between motivation and need in general (Kutlu \& Canbolat Bozkurt, 2018, p. 201). Another reason that affects motivation is the person's views and thoughts about his own abilities. While self-confidence, self-esteem and successes increase intrinsic motivation, experienced failures decrease it (Kutlu \& Canbolat 
Bozkurt, 2018, p. 206).

On the other hands, significant achievement in anything - athletics, the arts, business, career, politics, personal relationships, school, even hobbies - takes a great deal of ongoing commitment, self-discipline and hard work (Semones, 1991, p. 5). Ongoin achievement in any life's endeavors can only be attained through action. World-class athletes, artists, and musicians reach high levels of achievement only as a result of almost fanatical practice and refinement of technique (Semones, 1991, p. 5).

Today, the concept of learning-learning has gained importance with the adoption of the Progressivist education philosophy and the development and implementation of the Constructivist Learning Theory.

According to the constructivist view, learning is the process of the student constructing his own reality (knowledge) in his mind regarding a certain object, event, phenomenon or concept that he perceives from the sensory organs and the outside world, or at least as the process of interpreting reality based on his previous experiences. In this process, the learner experiences by interacting with the environment, and interprets and interprets the new information according to himself, in short, he internalizes it, accepts the information in accordance with his own reality. Thus, new information is built on previously structured information.

This study was conducted to examine the "Studying and Learning Strategies" used by students studying in two general high school types (Science and Anatolian High Schools) in the General Secondary Education level in the Turkish Education System both at grade levels (9th and 12th grades) and by gender. High schools in the Turkish Education System are divided into two main groups as types. One of them is General High Schools and the other is Vocational and Technical High Schools. General High Schools are divided into two sub-types as Science and Anatolian High Schools. Science high schools are high schools where students who are more academically successful than Anatolian High Schools are accepted. With this study, "Studying and Learning Strategies" used by students studying in these two types of high schools; The school type was analyzed comparatively according to the gender and grade levels of the students. Thus, it will be determined how effective the "Studying and Learning Strategies" are especially in academic success, and what the Study and Learning Strategies preferred by the students in the more successful school types will be determined. Thus, as a result of the study, it is expected that a guidance will be made for the students about Studying and Learning.

The general purpose of this study is to comparatively examine the "Studying and Learning Strategies" used by the students of Science and Anatolian High Schools. In line with this general purpose, the following questions were sought;

1) Is there any difference between the "Studying and Learning Strategies" used by the students of Science and Anatolian High Schools according to their "School Types"?

2) Is there any difference between the "Studying and Learning Strategies" used by the students studying at Science and Anatolian High Schools according to their "Gender"?

3) Is there any difference between the "Studying and Learning Strategies" that Science and Anatolian High School students use according to their "Gender" on the basis of school types?

4) Is there any difference between the "Studying and Learning Strategies" used by the students of Science and Anatolian High Schools according to the "9th and 12th Grade Levels"?

5) Is there a difference between the "Studying and Learning Strategies" that Science and Anatolian High School students use according to their "9th and 12th Grades" on the basis of school types?

\section{Method}

\subsection{Research Design}

The study is a descriptive study, a relational survey model. Büyüköztürk (2019, p. 16) state that such research has been done, who wants to identify the relationships between two or more variables and to obtain clues about cause and effect. The research was conducted with this model cross-sectional scanning sectional area (Karasar, 2006, p. 80). In the research, the learning, studying and learning strategies of 9th and 12th grades of Anatolian and Science High Schools were compared and examined.

\subsection{Population and Sample}

The population of the study is 9th and 12th grade students who are studying in Anatolian and Science High Schools in the city center of Adana. The study group of the research consisted of 393 students in 9th and 12th grades who were studying at Adana Science High School and Seyhan 24th November IMKB Anatolian High School in the spring term of the 2019-2020 academic year. Since the field preferences in high schools are made 
from the 11th grade, all of the 12th grade students in Science and Anatolian High Schools were especially selected from "Numerical Field" students. For this reason, Purposive Sampling Method (Frenkel \& Wallen, 1993, p. 89) was preferred in the sample selection of the study.

\subsection{Data Collection Tools}

As a data collection tool, the "Study and Learning Strategies Scale for High School Students" developed by Kutlu, Yapicı and Korkmaz (2015, pp. 27-32), consisting of 46 items and five sub-dimensions, was used. These sub-dimensions are:

(1) Associating the Learned

(2) Repeating

(3) Showing Determination in Learning

(4) Enjoying Learning

(5) Self-Confidence in Learning Process

\subsection{Data Analysis}

Regarding the data in this study, the Central Trend Measures (Descriptive Statistics); Arithmetic Mean (Mean/ $/ \bar{x})$, Standard Deviation (SD), Degree of Freedom (DF) were obtained, and then to determine whether there are differences between groups; "Independent Samples t-test for Independent Samples" analysis was performed.

\section{Results}

\subsection{The Levels of "Using Learning and Studying Strategies" According to the School Types of Students}

The levels of "using learning and studying strategies" according to the school types of students are presented in Table 1.

Table 1. The levels of "using learning and studying strategies" according to the school types of students

\begin{tabular}{|c|c|c|c|c|c|c|c|c|}
\hline Strategies & School Type & $\mathbf{N}$ & $\overline{\mathbf{x}}$ & SD & SE & df & $\mathbf{t}$ & $\mathbf{p}$ \\
\hline \multirow[t]{2}{*}{ Overarching } & Science High School & 175 & 27.2514 & 5.52369 & .41755 & 390 & 1.864 & .063 \\
\hline & Anatolia High School & 217 & 26.1475 & 6.06419 & .41166 & & & \\
\hline \multirow[t]{2}{*}{ Repeat } & Science High School & 175 & 12.7943 & 3.18094 & .24046 & 390 & -2.995 & $.003 *$ \\
\hline & Anatolia High School & 217 & 13.8249 & 3.54426 & .24060 & & & \\
\hline \multirow[t]{2}{*}{ Determination } & Science High School & 176 & 12.2557 & 3.43386 & .25884 & 391 & 1.125 & .261 \\
\hline & Anatolia High School & 217 & 11.8479 & 3.68303 & .25002 & & & \\
\hline \multirow[t]{2}{*}{ Delight in Learning } & Science High School & 176 & 7.0511 & 1.67765 & .12646 & 391 & -7.575 & $.000^{*}$ \\
\hline & Anatolia High School & 217 & 8.2995 & 1.58045 & .10729 & & & \\
\hline \multirow[t]{2}{*}{ Confidence } & Science High School & 176 & 7.2670 & 1.77031 & .13344 & 391 & .662 & .508 \\
\hline & Anatolia High School & 217 & 7.1521 & 1.66386 & .11295 & & & \\
\hline
\end{tabular}

Note. ${ }^{*} \mathrm{p}<.05$.

As seen in Table 1, when examining the students' level of using "Studying and Learning Strategies" according to School Types; It was determined that there was a significant difference in the sub-dimensions of "Repetition" and "Enjoying Learning" [ $\mathrm{t}(390),-2.995, \mathrm{p}<.05]$ and [ $\mathrm{t}(391),-7.575, \mathrm{p}<.05]$. When the Arithmetic Averages $(\overline{\mathrm{x}})$ are examined, the strategies of "Repetition" ( $\overline{\mathrm{x}}=13.82$ and $\overline{\mathrm{x}}=12.79)$ and "Enjoying Learning" $(\overline{\mathrm{x}}=8.29$ and $\overline{\mathrm{x}}=7.05$ ) of Anatolian High School students are it has been seen that they prefer more than that. It can be said that the main reason for this situation stems from the fact that Science high school students do not need to repeat much for learning or their self-confidence, compared to Anatolian high school students. As it is known, learning is a necessity and in this respect it is a reward. In addition, learning is an effective source of motivation. According to this result, it is seen that Anatolian High School students are more motivated in their learning process. On the other hand, it is also seen in the table that almost a meaningful result can be found among the groups in favor of Science High School students in the "Association" strategy $(\mathrm{p}=.063)$. In this sub-dimension, it is seen that Science High School students use this strategy more than Anatolian High School students $(\overline{\mathrm{x}}=$ 27.25 and $\overline{\mathrm{x}}=26.14$ ). This situation may also explain why Science High School students are more successful.

\subsection{The Levels of "Using Learning and Studying Strategies" According to Students' Gender}

The levels of "using learning and studying strategies" according to students' gender are presented in Table 2. 
Table 2. The levels of "using learning and studying strategies" according to students' gender

\begin{tabular}{|c|c|c|c|c|c|c|c|c|}
\hline Strategies & Gender & $\mathbf{N}$ & $\overline{\mathbf{x}}$ & SD & SE & df & $\mathrm{t}$ & $\mathbf{p}$ \\
\hline \multirow[t]{2}{*}{ Overarching } & $\mathrm{F}$ & 224 & 26.8036 & 5.83762 & .39004 & 389 & .703 & .483 \\
\hline & M & 167 & 26.3832 & 5.86673 & .45398 & & & \\
\hline \multirow[t]{2}{*}{ Repeat } & F & 224 & 13.8080 & 3.40584 & .22756 & 389 & 3.042 & $.003 *$ \\
\hline & M & 167 & 12.7545 & 3.36256 & .26020 & & & \\
\hline \multirow[t]{2}{*}{ Determination } & $\mathrm{F}$ & 225 & 12.1956 & 3.58157 & .23877 & 390 & 1.109 & .268 \\
\hline & M & 167 & 11.7904 & 3.56663 & .27599 & & & \\
\hline \multirow[t]{2}{*}{ Delight in Learning } & F & 225 & 7.8444 & 1.70812 & .11387 & 390 & 1.419 & .157 \\
\hline & M & 167 & 7.5928 & 1.77382 & .13726 & & & \\
\hline \multirow[t]{2}{*}{ Confidence } & $\mathrm{F}$ & 225 & 6.8444 & 1.60295 & .10686 & 390 & -4.932 & $.000^{*}$ \\
\hline & $\mathrm{M}$ & 167 & 7.6826 & 1.74276 & .13486 & & & \\
\hline
\end{tabular}

Note. $* \mathrm{p}<.05$.

When Table 2 is analyzed, it is observed that there is a significant difference between male and female students in the sub-dimensions of "Repetition" and "Self-Confidence" in terms of "Using Study and Learning Strategies" according to the gender of the students, respectively; [ $(389), 3.042, \mathrm{p}<.05]$ and [ $\mathrm{t}(390),-4.932, \mathrm{p}<.05]$ are seen. When the arithmetic means between genders in the "repeat" strategy were examined, it was determined that girls repeat lesson more than boys $(\overline{\mathrm{x}}=13.80$ and $\overline{\mathrm{x}}=12.75)$. As is known, it is a strategy to combat forgetting again. It is seen that female students use this strategy more to prevent forgetting what has been learned. On the other hand, it is striking that male students are more self-confident than female students in the learning process in a way to support this tendency $(\overline{\mathrm{x}}=6.84$ and $\overline{\mathrm{x}}=7.68)$.

\subsection{The Levels of "Using Learning and Studying Strategies" According to the Types of Schools and Gender of the} Students

The levels of "using learning and studying strategies" according to the types of schools and gender of the students are presented in Table 3.

Table 3. The levels of "using learning and studying strategies" according to the types of schools and gender of the students

\begin{tabular}{|c|c|c|c|c|c|c|c|c|c|}
\hline SchTy & Strategies & Gender & $\mathbf{N}$ & $\overline{\mathbf{x}}$ & SD & SE & df & $\mathrm{t}$ & $\mathbf{p}$ \\
\hline Science & Overarching & $\mathrm{F}$ & 97 & 27.4845 & 5.21039 & .52904 & 172 & .713 & .477 \\
\hline High & & M & 77 & 26.8831 & 5.90935 & .67343 & & & \\
\hline \multirow[t]{8}{*}{ School } & Repeat & $\mathrm{F}$ & 97 & 13.0103 & 3.07034 & .31175 & 172 & 1.092 & .276 \\
\hline & & M & 77 & 12.4805 & 3.31111 & .37734 & & & \\
\hline & Determination & $\mathrm{F}$ & 98 & 12.2755 & 3.41247 & .34471 & 173 & .154 & .878 \\
\hline & & M & 77 & 12.1948 & 3.49074 & .39781 & & & \\
\hline & Delight in Learning & $\mathrm{F}$ & 98 & 7.2449 & 1.63758 & .16542 & 173 & 1.837 & .068 \\
\hline & & M & 77 & 6.7792 & 1.69848 & .19356 & & & \\
\hline & Confidence & $\mathrm{F}$ & 98 & 6.8367 & 1.63527 & .16519 & 173 & -3.713 & $.000 *$ \\
\hline & & M & 77 & 7.8052 & 1.80671 & .20589 & & & \\
\hline Anatolia & Overarching & $\mathrm{F}$ & 127 & 26.2835 & 6.24487 & .55414 & 215 & .392 & .696 \\
\hline High & & M & 90 & 25.9556 & 5.82885 & .61442 & & & \\
\hline \multirow[t]{8}{*}{ School } & Repeat & $\mathrm{F}$ & 127 & 14.4173 & 3.53316 & .31352 & 215 & 2.978 & $.003 *$ \\
\hline & & M & 90 & 12.9889 & 3.40685 & .35911 & & & \\
\hline & Determination & $\mathrm{F}$ & 127 & 12.1339 & 3.71902 & .33001 & 215 & 1.361 & .175 \\
\hline & & M & 90 & 11.4444 & 3.61368 & .38092 & & & \\
\hline & Delight in Learning & $\mathrm{F}$ & 127 & 8.3071 & 1.62086 & .14383 & 215 & .083 & .934 \\
\hline & & M & 90 & 8.2889 & 1.53055 & .16133 & & & \\
\hline & Confidence & $\mathrm{F}$ & 127 & 6.8504 & 1.58404 & .14056 & 215 & -3.242 & $.001 *$ \\
\hline & & M & 90 & 7.5778 & 1.68921 & .17806 & & & \\
\hline
\end{tabular}

Note. $* \mathrm{p}<.05$.

When Table 3 is examined, similar to Table 2, it is seen that there is a significant difference between male and female students in favor of male students $(\overline{\mathrm{x}}=7.80$ and $\overline{\mathrm{x}}=6.83)$ in the "Self-Confidence" subscale of Science High School students [ $\mathrm{t}(173),-3.713, \mathrm{p}<.05]$. Although there is no significant difference between the groups ( $\mathrm{p}$ $=.068$ ), it can be regarded as an interesting result that female students reported more opinions in the "Enjoying 
Learning" sub-dimension than male students among Science High School students $(\overline{\mathrm{x}}=7.24$. and $\overline{\mathrm{x}}=6.77)$. Similarly, in the "Self-Confidence" sub-dimension among Anatolian High School students, there is a significant difference in favor of male students $(\overline{\mathrm{x}}=7.57$ and $\overline{\mathrm{x}}=6.85)(\mathrm{t}(215),-3.242, \mathrm{p}<.05]$. In addition, it was determined that there is a difference in favor of female students $(\overline{\mathrm{x}}=14.41$ and x $12=12.98)$ between male and female students in the "Repeat" strategy used by Anatolian High School students [t (215), 2.978, p < .05].

3.4 The Levels of "Using Studying and Learning Strategies" According to Students' Grade Levels

The levels of "using studying and learning strategies" according to students' grade levels are presented in Table 4.

Table 4. The levels of "using studying and learning strategies" according to students' grade levels

\begin{tabular}{|c|c|c|c|c|c|c|c|c|}
\hline Strategies & Degree & $\mathbf{N}$ & $\overline{\mathbf{x}}$ & SD & SE & df & $\mathbf{t}$ & p \\
\hline \multirow{2}{*}{ Overarching } & 9 & 261 & 26.4406 & 5.74199 & .35542 & 390 & -.954 & .341 \\
\hline & 12 & 131 & 27.0382 & 6.05539 & .52906 & & & \\
\hline \multirow[t]{2}{*}{ Repeat } & 9 & 261 & 13.3716 & 3.46685 & .21459 & 390 & .056 & .955 \\
\hline & 12 & 131 & 13.3511 & 3.34186 & .29198 & & & \\
\hline \multirow[t]{2}{*}{ Determination } & 9 & 262 & 11.8740 & 3.54222 & .21884 & 391 & -1.228 & .220 \\
\hline & 12 & 131 & 12.3435 & 3.63270 & .31739 & & & \\
\hline \multirow[t]{2}{*}{ Delight in Learning } & 9 & 262 & 7.7328 & 1.78037 & .10999 & 391 & -.123 & .902 \\
\hline & 12 & 131 & 7.7557 & 1.65526 & .14462 & & & \\
\hline \multirow[t]{2}{*}{ Confidence } & 9 & 262 & 7.1412 & 1.67444 & .10345 & 391 & -1.021 & .308 \\
\hline & 12 & 131 & 7.3282 & 1.78215 & .15571 & & & \\
\hline
\end{tabular}

Note. $* \mathrm{p}<.05$.

When Table 4 is examined, there is no difference between the "Using Study and Learning Strategies" levels of the 9th and 12th grade students studying at Science and Anatolian High Schools according to their grade levels.

\subsection{The Levels of "Using Learning and Studying Strategies" According to the Types of Schools and Class Levels of Students}

The levels of "using learning and studying strategies" according to the types of schools and class levels of students are presented in Table 5.

Table 5. The levels of "using learning and studying strategies" according to the types of schools and class levels of students

\begin{tabular}{|c|c|c|c|c|c|c|c|c|c|}
\hline SchoolTyp & Strategies & Degree & $\mathbf{N}$ & $\overline{\mathbf{x}}$ & SD & SE & df & $\mathbf{t}$ & $\mathbf{p}$ \\
\hline \multirow{10}{*}{$\begin{array}{l}\text { Science High } \\
\text { School }\end{array}$} & Overarching & 9 & 120 & 26,7083 & 5,38656 & ,49172 & 173 & $-1,936$ &, 054 \\
\hline & & 12 & 55 & 28,4364 & 5,68221 & ,76619 & & & \\
\hline & Repeat & 9 & 120 & 12,6083 & 3,15775 & ,28826 & 173 & $-1,143$ &, 254 \\
\hline & & 12 & 55 & 13,2000 & 3,22261 & ,43454 & & & \\
\hline & Determination & 9 & 121 & 11,6281 & 3,39885 & ,30899 & 174 & $-3,726$ &, $000^{*}$ \\
\hline & & 12 & 55 & 13,6364 & 3,11724 & ,42033 & & & \\
\hline & Delight in & 9 & 121 & 7,0579 & 1,71414 & ,15583 & 174 & ,079 & ,937 \\
\hline & Learning & 12 & 55 & 7,0364 & 1,60973 & ,21706 & & & \\
\hline & Confidence & 9 & 121 & 7,2314 & 1,58514 & , 14410 & 174 &,- 395 & ,693 \\
\hline & & 12 & 55 & 7,3455 & 2,13627 & ,28805 & & & \\
\hline \multirow{10}{*}{$\begin{array}{l}\text { Anatolia High } \\
\text { School }\end{array}$} & Overarching & 9 & 141 & 26,2128 & 6,03775 &, 50847 & 215 &, 216 &, 830 \\
\hline & & 12 & 76 & 26,0263 & 6,15137 &, 70561 & & & \\
\hline & Repeat & 9 & 141 & 14,0213 & 3,59458 & ,30272 & 215 & 1,112 & ,267 \\
\hline & & 12 & 76 & 13,4605 & 3,44264 & ,39490 & & & \\
\hline & Determination & 9 & 141 & 12,0851 & 3,65960 & ,30819 & 215 & 1,294 & ,197 \\
\hline & & 12 & 76 & 11,4079 & 3,71009 & ,42558 & & & \\
\hline & Delight in & 9 & 141 & 8,3121 & 1,63066 & ,13733 & 215 & ,159 & ,874 \\
\hline & Learning & 12 & 76 & 8,2763 & 1,49308 & ,17127 & & & \\
\hline & Confidence & 9 & 141 & 7,0638 & 1,74934 & ,14732 & 215 & $-1,064$ & ,288 \\
\hline & & 12 & 76 & 7,3158 & 1,48961 & 17087 & & & \\
\hline
\end{tabular}

Note. ${ }^{*} \mathrm{p}<.05$. 
When Table 5 is examined, among the "Sing Study and Learning Strategies "according to the grade levels of the 9th and 12th grade students studying in Science and Anatolian High Schools, only in favor of the 12th grade students in the" Determination "sub-dimension in Science High Schools ( $\overline{\mathrm{x}}=13.63$ and $\overline{\mathrm{x}}=11.62)$ [t (174), -3.726, $\mathrm{p}<.05] .12$. The main reason for this may be that the University Entrance Exams are held at the end of the 12th grade and therefore the Science High School students show more "determination" in their study and learning processes. In addition, it is striking that there is an almost significant difference $(p=.054)$ in favor of the 12th grade students $(x=28.43$ and $\bar{x}=26.70)$ in the "association" sub-dimension in Science High School for similar reasons.

\section{Conclusion, Discussion, and Recommendations}

In this study, the "Studying and Learning Strategies" used by students studying in two general high schools (Science and Anatolian High Schools) in the General Secondary Education level in the Turkish Education System were compared both at grade levels (9th and 12th grades) and according to the gender of the students.

As a result of the study, when the Study and Learning Strategies of the students are examined according to school types; It was determined that there is a significant difference in the sub-dimensions of "Repetition" and "Enjoying Learning". It was observed that Anatolian High School students used the strategies of "Repeating" and "Enjoying from Learning/Willing to Learn" more than Science High School students. According to this result, it is seen that Anatolian High School students are more motivated in their learning process. On the other hand, it is also seen in the table that a meaningful result can be found in favor of Science High School students among the groups in the "Association" strategy. In this sub-dimension, it is seen that Science High School students use this strategy more than Anatolian High School students. This situation may also explain why Science High School students are more successful.

It has been observed that there is a significant difference between male and female students in "Repetition" and "Self-Confidence" sub-dimensions in terms of "Using Study and Learning Strategies" according to the gender of the students. In the "repeat" strategy, it can be accepted as the main reason for this situation that girls repeat lesson more than boys and male students have more self-confidence in the learning process than female students in a way to support this tendency, and consequently less repetition.

On the other hand, it is observed that there is a significant difference between male and female students in favor of male students in the "Self-Confidence" sub-dimension of Science High School students. Although there is no statistically significant difference between the groups, it can be accepted as an interesting result that among the Science High School students, female students reported more opinions in the "Getting Enjoyment from Learning" sub-dimension compared to male students. Similarly, among Anatolian High School students, it is observed that there is a significant difference in favor of male students between male and female students in the "Self-Confidence" sub-dimension. In addition, it was determined that there is a difference in favor of female students in the "Repeat" strategy used by Anatolian High School students.

There was no significant difference between the "Using Study and Learning Strategies" levels of 9th and 12th grade students studying at Science and Anatolian High Schools according to their grade levels. However, there is a significant difference in favor of 12th grade students only in the "Determination" sub-dimension of the Science High School between the levels of "Using Study and Learning Strategies" based on the school types of 9th and 12th grade students studying in Science and Anatolian High Schools has been seen. As is known, University Entrance Exams are held at the end of 12 classes. For this reason, Science High School students may have preferred to show more "Determination" in their study and learning processes. Also, for the same reason, it is a striking finding that there is almost a significant difference in favor of 12th grade students in the "association" sub-dimension in Science High School.

It is likely to make some recommendations after examining this study results:

- In addition to this research conducted only in Science and Anatolian High Schools, similar studies can be conducted in all school levels and types, including higher education, with longitudinal or sectional approaches at different grade levels,

- Experimental studies on Study and Learning Strategies can be conducted in every school grade and type.

\section{References}

Büyüköztürk, Ş., Kılıç, Ç. E., Akgün, Ö. E., Karadeniz, Ş., \& Demirel, F. (2019). Scientific research methods in education. Ankara: PEGEM Akademi.

Fraenkel, J. R., \& Wallen, N. E. (1993). How to design and evaluate research in education. McGraw-Hill Book 
Co. N.Y.

Frender, G. (2004). Learning to learn, strengthening study skills and brain power. Tenessee: Incentive Publications.

Grellet, F. (1981). Developing reading skills. London: Cambridge University Press.

Jonassen, D. H. (1994). Toward a constructivist design model. Education Technology, 31(6), 35-37.

Karasar, N. (2006). Scientific research methods. Ankara: Nobel Publishing House.

Kirby, J. R. (1988). Learning strategies and learning. In R. R. Schmeck (Ed.), Style, strategy and skill in reading (pp. 229-274). New York/London: Plenum Press. https://doi.org/10.1007/978-1-4899-2118-5_9

Klein, S. B. (1991). Learning principles and applications. McGraw-Hill, Inc. N.Y.

Kutlu, M. O., \& Canbolat, B. M. (2018). Knows enough who knows how to learn. Konya: Çizgi Publishing House.

Kutlu, M. O., Yapıcı, A., \& Korkmaz, Ş. (2015). A scale development on study and learning strategies for high school students- adana sample from Turkey. International Multilingual Journal of Contemporaray Research, 3(2), 27-32. https://doi.org/10.15640/imjcr.v3n2a3

Lefrançois, G. R. (2000). Theories of learning: What the old man said. Belmont: Wadsworth Thomson Learning.

Luckie, R. W., \& Smethurst, W. (1998). Study power, study skills to improve your learning and your grades. Massachusetss: Brookline Books.

Mundsack, A., Deese, J., \& Deese, E. K. (2003). How to study. McGraw-Hill, N.Y.

O’Hara, S. (2005). Improving your study skills. Wiley Publishing, Inc. N.J.

Rowntree, D. (1998). Learn how to study. London: Warner Books.

Samones, K. J. (1991). Effective study skills. Harcourt Brace Collage Publishers, N.Y.

Simsson, S. (2000). Essential study skills. Kindle Edition. Retrieved from http://www.amazon.com

Türkoğlu, A., Doğanay, A., \& Yıldırım, A. (1996). Study skills. Adana: Baki Kitabevi.

VonderStoep, S. W., \& Pintrich, P. R. (2003). Learning to learn, the skill, and will of college success. Pearson Education, Inc, N.J.

Wlodkowski, R. J., \& Jaynes, J. H. (1991). Eager to learn. San Francisco: Jossey-Bass Publishers.

\section{Copyrights}

Copyright for this article is retained by the author, with first publication rights granted to the journal.

This is an open-access article distributed under the terms and conditions of the Creative Commons Attribution license (http://creativecommons.org/licenses/by/4.0/). 